\title{
RINGKASAN
}

\section{KARAKTERISASI ENZIM EKSTRASELULER PADA SUBSTRAT INULIN \\ DAN MOLEKULER GEN LEVANASE DARI \\ BAKTERI TERMOFILIK Bacillus licheniformis UBCT-007 \\ ISOLAT LOKAL SUMATERA BARAT}

Oleh:

\section{Minda Azhar}

\author{
No.BP \\ : 0831201006 \\ Program Studi \\ : Doktor Ilmu Kimia \\ Kelompok Bidang Studi : Biokimia, Bioteknologi
}

Bakteri termofilik pendegradasi inulin merupakans sumber potensial enzim pendegradasi inulin termostabil. Tujuan penelitian adalah menskrining dan mengidentifikasi isolat bakteri pendegradasi inulin dari sumber air panas di Solok Sumatera Barat, menentukan karakteristik enzim ekstraseluler isolat UBCT-007 pada substrat inulin, mencari gen penyandi enzim pendegradasi inulin pada isolat UBCT-007, mengkaji model struktur tersier enzim pendegradasi inulin secara in silico.

Metode penelitian yang dilakukan meliputi skrining bakteri pendegradasi inulin pada media yang mengandung inulin dan inulin-Remazol Briliant Blue (inulin-RBB) sebagai satu-satunya sumber karbon. Identifikasi bakteri dilakukan pada tingkat genotip dan fenotip. Identifikasi bakteri secara genotip berdasarkan kemiripan urutan basa nukleotida gen 16S rRNA UBCT-007 dengan urutan basa nukleotida gen 16S rRNA pada basis data GenBank. Identifikasi bakteri pada tingkat fenotip dilakukan berdasarkan morfologi koloni, mikroskopik sel dan sifat-sifat fisiologi bakteri. Karakteristik enzim ekstraseluler dilakukan uji tipe aksi enzim dengan thin layer chromatography (TLC), aktivitas enzim pada inulin dapat larut pada variasi $\mathrm{pH}$ dan suhu, aktivitas enzim pada granula inulin dengan scanning electron microscope (SEM), Gula pereduksi yang terbentuk akibat aktivitas enzim ditentukan menggunakan metoda Semogyi-Nelson. Enzim dimurnikan secara parsial dengan ammonium sulfat dan profil protein dianalisis dengan elektroforesis gel sodium dodecyl sulphate polyacrylamide (SDS-PAGE). Gen pengkode enzim pendegradasi inulin diisolasi menggunakan metoda polymerase chain reaction (PCR). Primer degeneratif dirancang berdasarkan domain lestari enzim pendegradasi inulin, sedangkan primer spesifik gen levanase dirancang dari beberapa urutan gen levanase Bacillus subtilis dari basis data GenBank. Fragmen dan gen levanase diklon pada vektor pGEM-T Easy dan disekuens dengan metoda dideoksi Sanger, selanjutnya ditranslasi secara in silico. Struktur tersier enzim ditentukan menggunakan program PHYRE.

Dua isolat bakteri pendegradasi inulin telah ditemukan dari sumber air panas di Solok Sumatra Barat, yaitu isolat UBCT-007 dan isolat UBCT-030. Isolat UBCT-007 memiliki kekerabatan terdekat dengan Bacillus licheniformis, sedangkan isolat UBCT030 memiliki kekerabatan terdekat dengan Bacillus subtilis. Karakteristik enzim 
ekstraseluler Bacillus licheniformis UBCT-007 menunjukkan aktivitas enzim ekstraseluler paling baik pada suhu $60^{\circ} \mathrm{C}$ dan $\mathrm{pH} 4,5$, dapat merusak bentuk granula inulin, bertipe aksi exo-, dan diperkirakan mempunyai massa molekul 57,2 kDa.

Pada Bacillus licheniformis UBCT-007 telah ditemukan dua gen exolevanase yang berukuran 2034 pb dan 2058 pb. Gen tersebut ditemukan dengan empat kali PCR. PCR pertama dan kedua menggunakan primer degeneratif. PCR pertama dan kedua masingmasing menghasilkan satu fragmen gen pendegradasi inulin berukuran 398 pb dan 539 pb. Fragmen gen berukuran $398 \mathrm{pb}$ terdapat pada fragmen gen $539 \mathrm{pb}$. Daerah hulu dan hilir pada fragmen gen 539 pb ditemukan dengan PCR ketiga dan keempat menggunakan primer spesifik.

Deduksi urutan lengkap gen exolevanase ukuran 2034 pb dan 2058 pb dari Bacillus licheniformis UBCT-007 menghasilkan protein BlcM sepanjang 677 residu asam amino dan BlcA sepanjang 685 residu asam amino. Peptida sinyal putatif pada BlcM adalah 24 residu asam amino, sedangkan pada BlcA adalah 32 residu asam amino. Perbedaan kedua protein ini terletak pada 8 residu asam amino pertama pada BlcA. Perbedaan selanjutnya adalah pada protein BlcM terdapat residu asam amino His67, dan Ser159, sedangkan pada BlcA adalah Asp75, dan Asn167. Protein BlcM dan BlcA membentuk kelompok cabang dengan levanase dari Bacillus subtilis.subsp. subtilis.str.168 (No. asesi CAZy, CAB14645.1) pada pohon filogenetik.

Model struktur tersier BlcM dan BlcA terdiri atas 2 domain yaitu domain $\beta$ propeller pada domain $\mathrm{N}$ terminal dan domain $\beta$-sandwich pada domain $\mathrm{C}$ terminal. Domain $\beta$-propeller terdiri dari 5 blade. Pada blade 1, dan blade 3 BlcM terdapat residu katalitik Asp49, dan Glu223, sedangkan pada BlcA adalah Asp57, dan Glu231. Domain $\beta$-sandwich pada BlcM dan BlcA terdiri dari dua $\beta$-sheet. Masing-masing $\beta$-sheet pada BlcM dan BlcA terdiri dari 5 dan $6 \beta$-strand antiparalel. Domain $\beta$-sandwich ini berbeda dengan domain $\beta$-sandwich yang telah ditemukan sebelumnya pada kelompok keluarga enzim GH32.

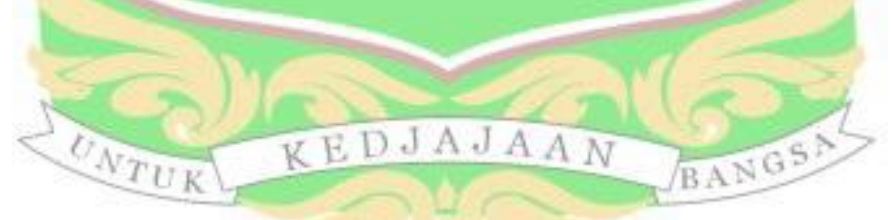




\section{SUMMARY \\ CHARACTERIZATION OF EXTRACELLULAR ENZYME ON INULIN SUBSTRATE AND MOLECULAR LEVANASE GENE FROM Bacillus licheniformis UBCT-007 THERMOPHILIC BACTERIA OF WEST SUMATERA LOCAL ISOLATE}

By

\section{Minda Azhar}

\author{
No.BP \\ Program of Study \\ Field of Study
}

\author{
: 0831201006 \\ : Chemistry (Doctor) \\ : Biochemistry, Biotechnology
}

Inulin degrading thermophilic bacteria are potential source of thermostable inulin degrading enzymes. The purposes of research were to screen and to identify inulin degrading bacteria from hot spring in Solok West Sumatra, to determine characteristics of extracellular enzymes UBCT-007 bacterial isolate on inulin substrate, to isolate genes of inulin degrading enzymes from UBCT-007 bacterial isolate and to analyze tertiary structure model of the enzyme.

Methods of the research were screening of inulin degrading bacteria in media containing inulin and inulin-Remazol Briliant Blue (inulin-RBB) as the sole carbon source. The inulin degrading bacteria were identified at genotype and phenotype level. The genotypic identification of bacteria based on similarity of 16S rRNA gene sequences UBCT-007 isolate with 16S rRNA gene in GenBank database. In phenotype level were observed colony morphology, microscopic cells and the nature of bacterial physiology. Characterizations of extracellular enzymes on inulin substrate were tested enzyme action type by using thin layer chromatography (TLC), enzyme activity on soluble inulin at the various $\mathrm{pH}$ and temperature, enzyme activity on granular inulin by using scanning electron microscope (SEM). Reducing sugar was determined by using Semogyi-Nelson method. The extracellular crude enzyme was purified partially by using ammonium sulfate and the protein profile was analysed by sodium dodecyl sulphate polyacrylamide gel electrophoresis (SDS-PAGE). Genes encoding for inulin degrading enzymes were isolated by using polymerase chain reaction (PCR) method. Degenerate primers were designed based on conserved domains of inulin degrading enzymes and specific primers from sequences of Bacillus subtilis levanase genes in GenBank were also used. DNA fragment and levanase genes were cloned into pGEM-T Easy and sequenced by dideoxy Sanger method, and then followed by in silico translation. Tertiary structures of enzyme were determined using PHYRE program.

Two inulin degrading bacteria, namely Bacillus licheniformis UBCT-007 and B. subtilis UBCT-030 have been found. The extracellular enzyme from Bacillus licheniformis UBCT-007 had optimal activity at temperature $60^{\circ} \mathrm{C}$ and $\mathrm{pH} 4.5$. It could degrade granular inulin, had exo- action type and was predicted to have a molecular mass of $57.2 \mathrm{kDa}$. Two exolevanase genes with the size of $2034 \mathrm{bp}$ and $2058 \mathrm{bp}$, respectively, 
have been isolated from $B$. licheniformis UBCT-007. The exolevanase genes was obtained using PCR four times. The first and second PCR using degenerative primers. The first and second PCR produced the gene fragment size $398 \mathrm{bp}$ and $539 \mathrm{bp}$. Size of 398 bp gene fragment contained in the 539 bp gene fragment. Upstream and downstream of $539 \mathrm{bp}$ gene fragment was found with third and fourth PCR using specific primers.

Deduction of nucleotide sequences of the levanase genes gave proteins designated as BlcM and BlcA, respectively. BlcM has 677 amino acid residues with 24 putative signal peptide, while BlcA is a polypeptide of 685 amino acid residues with 32 putative signal peptide. The first eight amino acids in the BlcA are different from the amino acids in BlcM. Furthermore, BlcM has His67 and Ser159 which correspond to Asp75, and Asn167 in BlcA. BlcM and BlcA protein formed a group of branches with levanase from Bacillus subtilis.subsp.subtilis.str.168 (CAZy accession no. CAB14645.1) on the phylogenetic tree.

Tertiary structure model of BlcM and/BlcA demonstrated that each protein has $\beta$ propeller domain at the $\mathrm{N}$ terminal domain and $\beta$-sandwich domain at the $\mathrm{C}$ terminal domain. The $\beta$-propeller domain consists of five blades and the $\beta$-sandwich domain build by two $\beta$-sheets. Catalytic residues on BlcM were Asp49, and Glu223 located on the blade 1 , and blade 3 respectively, whereas the catalytic residues of BlcA were Asp57, and Glu231. Each $\beta$-sheet of $\beta$-sandwich domain on BlcM and BlcA consists of 5 and 6 antiparallel $\beta$-strand. $\beta$-sandwich domain was different from the $\beta$-sandwich domain that have been found previously in family GH32 enzymes.

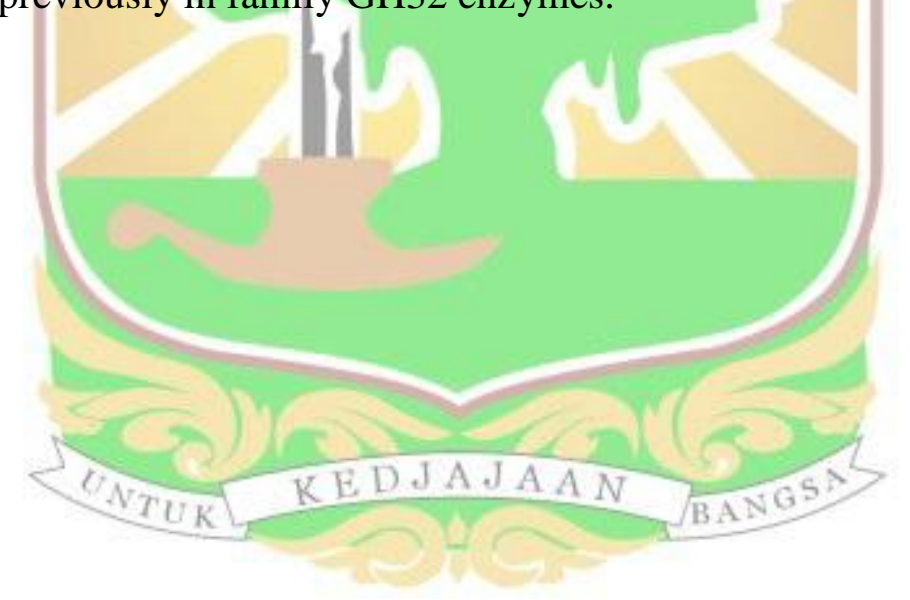

